\title{
Consistency between Constructivist Profiles and Instructional Practices of Prospective Physics Teachers *
}

\author{
Ozlem Ates ** \\ Manisa Celal Bayar University, TURKEY
}

\author{
Gul Unal Coban \\ Dokuz Eylul University, TURKEY
}

\author{
Serap Kaya Sengoren \\ Dokuz Eylul University, TURKEY
}

Received: February 15, 2018 - Revised: March 28, 2018 - Accepted: March 29, 2018

\begin{abstract}
This study aims to explain the extent to which prospective physics teachers' views and practices are consistent with the constructivist framework. A case study design was employed as the research approach. The study was conducted with 11 prospective physics teachers attending a state university in Turkey. Data was collected through semi-structured interviews, observation notes and lesson plans. The interview guide consisted of questions which allowed the interviewer to probe participants' views of constructivism based on 5E learning model. Such questions as "how do you plan your teaching?" (introducing new topics, continuing the lecture, types of questions to ask, evaluating students' understanding etc.) were included in the interview. Following the analysis of the interview data, participants' profiles were classified into three categories: traditional, transition and constructivist under the dimensions "beginning of a lesson," "learning process," "learning environment" and "assessment." Observations were carried out using an observation checklist consisting of 24 items based on 5E learning model. Another checklist developed by the researchers was used to evaluate participants' teaching qualifications. Interview results showed that seven participants had transitional, three had constructivist and one had traditional views. However, none of the participants were observed to exhibit constructivist teaching styles. Moreover, observation and interview results were consistent only for six participants, indicating that almost half of the participants had difficulty putting their views into practice.
\end{abstract}

Keywords: Constructivism, prospective physics teachers, teaching practice, teacher education.

To cite this article: Ates, O., Unal Coban, G. \& Kaya Sengoren, S. (2018). Consistency between constructivist profiles and instructional practices of prospective Physics teachers. European Journal of Educational Research, 7(2), 359-372. doi: 10.12973/eujer.7.2.359

\section{Introduction}

As the educational paradigm has shifted from behaviorism to constructivism over the last decades, teachers' views, instructional practices and relationships with one another have had an essential place in educational research, especially in studies on teaching and teacher education. According to constructivists, peoples' actions may be mainly based on their preformed ideas (Tsai, 2002). This recent change in perspective has sparked much interest among researchers in gaining a better understanding of teachers' views and their role in teaching.

Research on science education has focused, especially for the last three decades, on science teachers' conceptions of teaching (Hewson \& Hewson, 1988), teaching and learning (Aguirre, Haggerty, \& Linder, 1990; Hashweh, 1996; Porlán, Martín, \& Pozo, 2004; Prawat, 1992; Smith \& Neale, 1989) relationship between science teachers' beliefs about teaching, learning and science (Bryan \& Gustafson, Brenda; Rowell, 2003; Gustafson, Rowell, \& Gustafson, Brenda J. ; Rowell, 1995; Tsai, 2002), teachers' understanding of nature of science and classroom practice (Brickhouse, 1990; Lederman, 1992; Mellado, 1997), preservice teachers' conceptions of teaching science, learning science, nature of science and its relation with their classroom practices (Mellado, 1998), effect of views on the implementation of science curriculum (Cronin-Jones, 1991), effect of teachers' personal practical theories on their curricular and instructional practices (Cornett, Yeotis, \& Terwilliger, 1990; Dillon, O’Brien, Moje, \& Stewart, 1994) and implications of teachers' views of science and learning on their use of teaching principles based on constructivism (Appleton \& Asoko, 1996).

Some studies (Appleton \& Asoko, 1996; Bassey, 1999; Nespor, 1987; Pajares, 1992; Qhobela \& Kolitsoe Moru, 2014) show that science teachers' instructional practices are, in some way, affected by their views of teaching. Some other studies, however, emphasize the differences between teachers' views and their instructional practices (Caleon, Tan, \& Cho, 2018; Justi \& Gilbert, 2002; Mansour, 2013; Savasci \& Berlin, 2012; Simmons et al., 1999). Lederman (1992) and

\footnotetext{
* This paper was partially presented at the World Conference of New Trends in Science Education (WCNTSE), Izmir, Turkey (September 19th -23rd 2011).

** Corresponding author:

Ozlem Ates , Manisa Celal Bayar University, Primary Education Department, Manisa, Turkey.
}

Email: hozlem@gmail.com 
Mellado (1997) argue that teachers' instructional practices may sometimes not be consistent with their own views of teaching and learning due to such factors as the nature of the curriculum and culture (Munby, Cunningham, \& Lock, 2000; Tobin \& Mcrobbie, 1996), assessment methods (Jenkins, 2000), choice of model or methodology (Munby, 1982) and social/physical structures (Hancock \& Gallard, 2004) affecting the way in which they put their views into practice.

As the principles of constructivist philosophy have been integrated into the Science and Technology Curriculum (since 2005) and the Physics, Chemistry, and Biology Curricula (since 2008), some studies have been conducted in Turkey, especially in the last ten years, on prospective teachers' beliefs about teaching and learning (Boz \& Uzuntiryaki, 2006; Demirci, 2015; Duru, 2006; Seda Cetin, Kaya, \& Geban, 2014) and the extent to which they put their views/beliefs into practice (Ogan-Bekiroglu \& Akkoc, 2009; Unal \& Akpinar, 2006; Uzuntiryaki, Boz, Kirbulut, \& Bektas, 2010). Based on those principles, students are expected to engage in activities both physically and mentally while tutors are expected to guide students' learning and to encourage them to perform activities to construct their own knowledge (Ates \& Eryilmaz, 2011). It is, therefore, of significance for prospective teachers to be knowledgeable about the philosophy of the curricula and have experience in constructivist-based teaching and learning practices. It is in fact difficult to compare the results of previous studies as they have used different methodologies to categorize teachers' views or actions according to the constructivist framework. Moreover, most studies are concerned with teachers' views of learning and teaching science rather than investigating their classroom practices and relations.

As noted earlier, there may be some factors causing an inconsistency between views and actions. It is, therefore, important to develop an appropriate framework to categorize and analyze teaching- and learning-related views and actions and their interrelationships, and to specify factors affecting classroom practices. In line with these considerations, this study aims to (1) elicit information on prospective physics teachers' teaching-and learning-related views to investigate their readiness for constructivist curriculum, (2) examine their instructional practices and (3) explore the consistency between their views and instructional practices.

The following research questions guided the present study:

1. Are prospective physics teachers' views consistent with the constructivist framework?

2. Are prospective physics teachers' instructional practices consistent with the constructivist framework?

3. Do prospective physics teachers put their views into practice?

\section{Methodology}

\section{Research Design}

Merriam (1998) states that qualitative research based on case study design is an appropriate way to provide a "holistic description and analysis of a single instance, phenomenon, or social unit" (p.27). Similarly, Yin (2009) describes case study as follows: "case study is used in many situations, to contribute to our knowledge of individual, group, organizational, social, political, and related phenomena" (p.18). Moreover, the size of the sample or the participants are methodologically important just for arriving at analytical generalizations apart from statistical generalizations (Bassey, 1999; Yin, 2009). Thus, case study design was the method of choice in this study to provide detailed and rich descriptions of a group of prospective teachers' views and actions in order to analyze and categorize them within the constructivist framework based on the $5 \mathrm{E}$ model and to determine whether there is a relationship between them.

\section{Participants}

The study was conducted with 11 fifth-grade physics students of the Department of Secondary Science and Mathematics Education at a university in the west of Turkey. Participants were recruited using purposive sampling. Physics students are required to take foundational knowledge courses (Physics, Optics, Electronics, Quantum Physics, Modern Physics, labs etc.), general pedagogical knowledge courses (Introduction to Teaching Profession, Curriculum Development and Instruction, Measurement and Evaluation, Methods of Physics Teaching, Instructional Technology and Material Development, Classroom Management, Guidance etc.), general knowledge courses (Principles of Ataturk and History of Revolutions, Turkish, Mathematics, English, Chemistry, etc.) and elective courses related to their program of study (Problem Solving in Physics, Astrophysics, Statistics in Physics Education etc.). Students have their first teaching experience during the Methods of Teaching course. They learn different teaching methods and have microteaching experiences during this course. They complete School Experience and Practice Teaching courses as practical courses in the last semesters of their programs of study. Each student is assigned a high school mentor teacher in the School Experience course. They observe their mentor teachers (regarding teaching methods, classroom management and assessment techniques etc.), students (e.g. a day of a student) and school environment to get an idea of teaching at a high school. In the Practice Teaching course, each student is again assigned a high school mentor teacher with whom they are supposed to prepare daily lesson plans and teach physics. Instructors from the department and mentor teachers evaluate their performance. During their practices, students try to apply the teaching and assessment methods and management techniques that they have learned during the pedagogical courses from previous semesters. Therefore, students have concentrated professional experience during their final year of school. 


\section{Instruments}

Semi-Structured Interviews: Interview guides were prepared by the researchers depending on literature review on prospective physics teachers' views of physics teaching and learning. Prior to primary data collection, the interview questions were piloted with three prospective physics teachers. The interviews were conducted by two trained researchers in Turkish and each lasted 30-45 minutes. All interviews were audio-recorded and then transcribed and coded by the researchers. The first interview guide (see Appendix) consisted of questions which sought to elicit information on prospective physics teachers' views of teaching and learning. The questions were prepared in accordance with the stages of the 5E learning model. Such questions as "how do you plan your teaching?" (introducing new topics, continuing the lecture, types of questions to ask, evaluating students' understanding etc.) were included in the interview. The second interviews were conducted after participants were observed during their classroom practices. Using the second interview guide (see Appendix), participants were asked to evaluate their teaching performance, to describe their teaching styles (during the observed classroom practice and their plans for future performance), and to explain the similarities and differences between what they planned to do during teaching and how they actually performed. The second interviews were conducted to enrich the data and to support the observations.

Observation Notes: The observations were carried out to understand whether participants' instructional practices were consistent with the constructivist framework and to find out whether they were able to put their views into practice. Participants' teaching practices were observed for two class hours at a high school during their final semester prior to graduation. The researchers were allowed by the school management in charge of vocational training to observe each participant for two hours.

Two researchers used an observation checklist developed by Unal and Akpinar (2006) to conduct the observations. Prepared in accordance with the 5E learning model, the observation checklist consisted of 24 items grouped into five phases: Engagement (6 items), exploration (5 items), explanation (5 items), elaboration ( 3 items) and evaluation (5 items). Table 1 shows some of the items in each phase.

Tally marks were used and brief notes were taken by the two researchers during participants' teaching practices. At the end of each lesson, both the marks and notes were converted into scores to represent the frequency of actions as "always," "frequently," "sometimes" and "never." Afterwards, the rates were classified into three models of instruction; traditional, transitional, or constructivist.

Table 1. Sample items of the observation checklist

5E phases Item

\begin{tabular}{|c|c|c|c|}
\hline 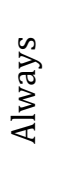 & 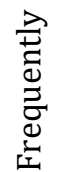 & 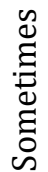 & $\begin{array}{l}\bar{d} \\
\bar{z} \\
z\end{array}$ \\
\hline
\end{tabular}

Captures students' attention (cartoon, photo, animation).

Engagement Motivates students to learn the subject matter/emphasizes its importance.

Introduces students to group work.

Guides students by asking questions when necessary.

Explanation

Explains new concepts based on students' prior knowledge.

Encourages students to explain their own interpretations.

Leads to discussion questions that reveal the relevance of the subject matter to others.

Elaboration Provides a suitable learning environment for students to use new concepts, definitions and information that they have learned.

Observes how much students apply their newly learned concepts.

Evaluation

Provides opportunities for students to evaluate themselves and group works. 
Another observation checklist was used to evaluate participants' teaching qualifications such as "subject expertise," "teaching methods," "keeping students physically and mentally active," "use of voice," "classroom management," "selfconfidence," etc. Possible scores for this observation checklist ranged from 0 to 18, with higher scores indicating higher teaching qualifications and more effective use of teaching methods. The researchers also took notes on what they found relevant to the items on the observation checklist.

Lesson Plans: In the practice teaching course, prospective teachers prepare daily lesson plans before their practical experience in a high school. Lesson plans include teaching and learning objectives, teaching materials, teaching methods, worksheets and assignments. Prospective teachers are supposed to explain in detail and step by step how they intend to attain their goals and use teaching methods, assignments, materials, etc. Lesson plans are a good source of information on how prospective teachers plan their instructional practices. Therefore, they provide researchers with the opportunity to compare teachers' intentions and their actual performance in class.

\section{Data Analysis}

Analysis of the Interview Transcripts: An initial list of keywords corresponding to the observation checklist was prepared in accordance with the 5E learning model in order to examine the interview transcripts. A framework was developed in line with this list to categorize participants' views as "traditional," "transitional" and "constructivist" (Table 2). Participants' responses indicating a weak understanding of constructivist principles were categorized as traditional. Contradictory or inconclusive responses indicating that participants have a basic understanding of but no sophisticated knowledge on constructivist principles were categorized as transitional. Lastly, responses yielding insight into constructivist principles were categorized as constructivist.

Including those categories, researchers have developed different frameworks for understanding teachers' views of teaching and learning science, and/or nature of science. According to Tsai (2002), "acquiring knowledge from credible sources," "focusing on scientific process or problem-solving procedures" and "constructing personal understanding" are descriptors for traditional, process and constructivist perspectives, respectively, for learning science. Unal and Akpinar (2006) classified science teachers' views as traditional, transitional and constructivist under the dimensions "prior knowledge," "learning climate" and "assessment." Similarly, prospective teachers' views were categorized as traditional, transitional or constructivist in this study. However, the dimensions were determined as "beginning of a lesson," "learning process," "learning environment" and "assessment." One might ask "why were the stages of the 5E learning model not used as the dimensions as in the observation checklist?" The answer is that an interview guide consisting of indirect questions about teaching and learning process, classroom environment and assessment techniques was used to receive responses with regard to participants' constructivist profiles. Moreover, participants' responses were more related to the specified dimensions than to the phases of the $5 \mathrm{E}$ model. Their views were, therefore, grouped under the dimensions "beginning of a lesson," "learning process," "learning environment" and "assessment." Incorporated into all dimensions, three phases (exploration, explanation and elaboration) of the 5E model were described in both the learning process and learning environment dimensions.

For example, the dimension "beginning of a lesson" includes codes related to the engagement phase. The dimension "learning process" includes students' roles related to the exploration, explanation and elaboration phases. Similarly, the dimension "learning environment" includes codes related to the role played by teachers in the exploration, explanation and elaboration phases and codes that are supposed to be provided by teachers for the learning environment. The "learning process" is related to learning while "learning environment" is related to teaching. Lastly, the dimension "assessment" consists of descriptions in the evaluation phase. Therefore, Table 2 was taken into account in the classification of participants' profiles regarding constructivism.

Table 2. Framework of categorizing participants' views

\begin{tabular}{|c|c|c|c|}
\hline Category & Traditional view & Transitional view & Constructivist view \\
\hline $\begin{array}{l}\text { Beginning of } \\
\text { a lesson }\end{array}$ & $\begin{array}{l}\text {-Teacher ignores } \\
\text { students' prior } \\
\text { knowledge } \\
\text {-Teacher especially asks } \\
\text { questions to repeat } \\
\text { previous lessons } \\
\text {-Teacher has no intention } \\
\text { of capturing students' } \\
\text { attention }\end{array}$ & $\begin{array}{l}\text {-Teacher asks questions not to } \\
\text { reveal the prior knowledge but to } \\
\text { find out what students know and } \\
\text { do not know } \\
\text {-Teacher has no conscious } \\
\text { intention of inducing curiosity, } \\
\text { making students aware of their } \\
\text { knowledge and encouraging them }\end{array}$ & $\begin{array}{l}\text {-Teacher pays attention to students' } \\
\text { prior knowledge } \\
\text {-Teacher captures students' } \\
\text { attention } \\
\text {-Teacher assesses students' prior } \\
\text { knowledge and knows why to use it }\end{array}$ \\
\hline $\begin{array}{l}\text { Learning } \\
\text { process }\end{array}$ & $\begin{array}{l}\text {-Students listen to the } \\
\text { teacher and take notes } \\
\text { during the lesson } \\
\text {-Interaction occurs if it is } \\
\text { possible and necessary }\end{array}$ & $\begin{array}{l}\text {-Students are active but not } \\
\text { throughout the entire process } \\
\text {-Students listen to their teacher } \\
\text { and take notes } \\
\text {-Students are actively involved in } \\
\text { problem-solving }\end{array}$ & $\begin{array}{l}\text {-Students are active throughout the } \\
\text { process and share their ideas } \\
\text {-Students do experiments and } \\
\text { participate in group discussions } \\
\text {-Students use what they learned to } \\
\text { explain new events }\end{array}$ \\
\hline
\end{tabular}


Table 2. Continued

\begin{tabular}{llll}
\hline Category & Traditional view & Transitional view & Constructivist view \\
\hline & -Teacher-centered & -Teacher transfers knowledge but & -Teacher creates a comfortable \\
& environment & tries to use different techniques, & environment in which students can \\
& -No effort to create an & and demonstrates & actively participate in their learning \\
Learning & environment in which & -Teacher tries to explorer & and share their views \\
environment & teacher interacts with & students' views and asks & -Teacher acts as a guide/facilitator \\
& students and ensures that & questions about them & and uses various instructional \\
& they are active & -Teacher tries to make students & techniques \\
& & active participants (partially) & -Teacher pays attention to group \\
& & & work and to interaction \\
& -Teacher assesses & -Teacher assesses students above & -Teacher assesses at all cognitive \\
& students at the & the knowledge level & levels \\
& knowledge level & -Both the learning process and & -Teacher pays attention to both \\
& -Teacher pays attention & product are important & process and product-oriented \\
& to product-oriented & -Both paper-pencil tests and & assessment \\
Assessment & alternative assessment techniques & -Teacher uses portfolios and open- \\
& assessment & are used & ended questions as well as paper- \\
& -Teacher uses paper- & & pencil tests \\
& pencil tests & & -Teacher uses self and peer \\
& & & assessment
\end{tabular}

The researchers scrutinized the interview transcripts individually. The inter researcher agreement for the classification of the dimensions "beginning of a lesson," "learning process," "learning environment" and "assessment" was .94, .92, .94 , and .96, respectively. In order to eliminate inter researcher disagreements, the transcripts were scrutinized until a consensus was reached and dimensions were finalized. The majority of the categories were taken into account when determining participants' overall category.

Analysis of the Observation Checklists: The researchers used tally marks and took notes while observing participants' teaching performance. At the end of each lesson, the marks and notes were converted into scores to determine how often participants engaged in specific activities during teaching. A 4-point rating expressed as "Always" (3), "Frequently" (2), "Sometimes" (1) and "Never" (0) was used. The observation statements were prepared positively. Therefore, total scores ranging from 0 to 24 indicated "a traditional model of instruction," those ranging from 25 to 48 indicated "a transitional model of instruction" and those ranging from 49 to 72 indicated "a constructivist model of instruction." The level of agreement between the researchers on the evaluation of observation scores was .88. In order to eliminate inter researcher disagreements, the researchers reexamined the ratings and notes until a consensus was reached and categories were finalized. There was no classification for the additional observation checklist. In order to check and interpret the other observation and interview results, participants were ranked according to their scores indicating their teaching qualifications and use of teaching methods.

\section{Results and Discussion}

Table 3 shows participants' views of their understanding of teaching and learning categorized as traditional, transitional and constructivist. Most participants had transitional views of the dimensions "learning process," "learning environment" and "assessment" and traditional views of the dimension "beginning of a lesson." Moreover, participants expressed more traditional views than constructivist views of the dimensions "beginning of a lesson," "learning environment" and "assessment," indicating that the number of participants who paid attention to students' prior knowledge, were aware of why they examined this knowledge and asked interesting inquiry questions was small. None of the participants had constructivist views of the assessment procedure, which may be due to the fact that most participants had either traditional or transitional views of teaching and learning.

Table 3. Participants' categorized views about teaching and learning

\begin{tabular}{lccc}
\hline Category & Traditional & Transitional & Constructivist \\
\hline Beginning of a lesson & 5 & 3 & 3 \\
Learning process & 3 & 5 & 3 \\
Learning environment & 3 & 6 & 2 \\
Assessment & 4 & 7 & 0 \\
\hline
\end{tabular}

Table 4 provides the possible combinations of participants' views across all dimensions and categories. The table shows that participants were not highly consistent in their views across all dimensions. Only two participants were consistent in their views (Murat for traditional and Deniz for transitional) across all dimensions. Others had either traditional-transitional, transitional-constructivist or traditional-constructivist views across all dimensions. None of the participants had traditional, transitional and constructivist views altogether across all dimensions. 
Tsai (2002) found that 30 (81\%) of 37 science teachers were consistent in their views of teaching and learning science. Similarly, Boulton-Lewis, Smith, McCrindle, Burnett and Campbell (2001) reported that 12 (75\%) of 16 teachers were consistent in their views of teaching and learning. However, (Caleon et al., 2018) reported that 5 (42\%) of 12 physics teachers were consistent in their beliefs about learning and teaching. The authors attributed this difference to the fact that the study focused on learning and teaching of a specific topic (electricity) rather than on science in general.

Similar to the results of most previous studies, 8 (73\%) participants in this study were consistent in their views of the learning process (related to learning physics) and learning environment (related to teaching physics). Of all combinations of the dimensions, the consistency between the dimensions "learning process" and "learning environment" was highest while that between the dimensions "beginning of a lesson" and "assessment" was lowest.

The category to which the majority of a participant's views belonged determined the overall category he or she was in. However, participants with two views falling within each category of "traditional" and "transitional" were placed in the latter. Similarly, those with two views falling within each category of "transitional" and "constructivist" were placed in the latter as an overall perspective.

Table 4 shows that seven participants had transitional, three had constructivist and one had traditional views, indicating that constructivist-oriented views were rarely expressed by participants. Moreover, most of them were inconsistent in their views, rendering them neither traditional nor constructivist.

Table 4. Possible combinations of participants' views

\begin{tabular}{|c|c|c|c|c|c|}
\hline $\begin{array}{l}\text { Prospective } \\
\text { teachers }\end{array}$ & $\begin{array}{l}\text { Beginning of } \\
\text { a lesson }\end{array}$ & $\begin{array}{l}\text { Learning } \\
\text { Process }\end{array}$ & $\begin{array}{l}\text { Learning } \\
\text { Environment }\end{array}$ & Assessment & Overall \\
\hline Hakan & Constructivist & Constructivist & Constructivist & Transitional & Constructivist \\
\hline Serap & Constructivist & Constructivist & Constructivist & Traditional & Constructivist \\
\hline Banu & Constructivist & Constructivist & Transitional & Transitional & Constructivist \\
\hline Deniz & Transitional & Transitional & Transitional & Transitional & Transitional \\
\hline Ersin & Traditional & Transitional & Transitional & Transitional & Transitional \\
\hline Derya & Traditional & Transitional & Transitional & Transitional & Transitional \\
\hline Beril & Traditional & Transitional & Traditional & Transitional & Transitional \\
\hline Eda & Transitional & Traditional & Transitional & Traditional & Transitional \\
\hline Sedat & Traditional & Transitional & Transitional & Traditional & Transitional \\
\hline Umut & Transitional & Traditional & Traditional & Transitional & Transitional \\
\hline Murat & Traditional & Traditional & Traditional & Traditional & Traditional \\
\hline
\end{tabular}

Table 5 shows the categorization of participants according to their observation scores, indicating that Derya had the lowest while Hakan had the highest observation score. Table 5 also presents the comparison of the interview and observation results. Contrary to the interview results, none of the participants were observed to conform with the constructivist profile. Moreover, as a result of the observations, two more participants were placed in the category of "traditional."

The comparison of the observation and interview data clearly showed that five (45\%) participants' views and practices were inconsistent. Three participants with constructivist views implemented transitional practices while the other two with transitional views implemented traditional practices. Only six participants (one traditional and five transitional) were categorized consistently as a result of the two analysis. Three of them were selected as the representatives of constructivist, transitional and traditional profiles. As a result of the analysis of the interviews, Murat and Deniz were categorized as traditional and transitional, respectively, for all dimensions and selected as cases for those profiles. No participant was categorized as constructivist according to the observation results. Though categorized as constructivist by the interview results and transitional by the observation results, Hakan was selected as the case for the constructivist profile as he had the highest observation checklist score.

Table 5. Participants' categorization based on interview and observation data

\begin{tabular}{lll}
\hline Participants & Observation Results & Interview Results \\
\hline Derya & Traditional & Transitional \\
Murat & Traditional & Traditional \\
Ersin & Traditional & Transitional \\
Deniz & Transitional & Transitional \\
Beril & Transitional & Transitional \\
Banu & Transitional & Transitional \\
Serap & Transitional & Constructivist \\
Eda & Transitional & Constructivist \\
Umut & Transitional & Transitional \\
Hakan & Transitional & Transitional \\
\hline
\end{tabular}


The names of participants whose second observation checklist scores ranged from lowest to highest are Derya, Sedat, Murat, Ersin, Beril, Deniz, Banu, Eda, Serap, Umut and Hakan. This ranking, which is very similar to that in Table 5, both confirms the consistency of the observation lists and provides information on participants' teaching qualities.

Participants' views of each dimension were evaluated and compared with the observation results in order to highlight and interpret the consistencies and contradictions between them. The following section elaborates on the cases and presents first the interview results and then the observation results of each dimension. Lastly, the section provides a summary of overall perspectives including a review of the lesson plans, participants' evaluation of the program and their self-evaluation of their practices. Participants' names were replaced with pseudonyms to maintain confidentiality.

\section{Case 1: Hakan (Constructivist Profile)}

Hakan was categorized as constructivist according to the interview results but transitional according to the observation notes. Having the highest observation checklist score, he was the most eligible candidate for the constructivist profile.

Views on beginning of a lesson: Hakan emphasized the importance of asking questions to capture students' attention and to test their prior knowledge at the beginning of a lesson. He stated his plans as:

Teachers should examine students' prior knowledge and ask questions. Then they should both ask questions and give information to students as to why the subject is taught, why it is important, how it is related to other subjects and how it can be related to real life.

During his lecture, he paid attention to this point (prior knowledge) in the introduction of the lesson. For example, while covering the topic of "introduction to modern physics," he asked such questions as "What are the latest discoveries in the field of physics?" "What do you think the discoveries in the field of physics are related to?" "What do you know about the CERN experiment?" He asked these questions to attract students' attention, to reveal their prior knowledge and to connect the subject matter to their daily lives. He gave the students enough time to answer the questions, and if they could not understand a question, he paraphrased it so that they could understand it. The observation results confirmed that his views of the beginning of a lesson were consistent with his actions.

Views on Learning Process: During the interview, he stated that students listened to their teachers passively while teachers lectured all the time, which to him was an inefficient learning process. He summarized his views of how learning process should be as follows:

When physics is associated with something concrete, it becomes meaningful to students since they become more curious and actively engage in posing questions and making comments. It is impossible for students to understand everything completely when teachers give direct instructions to them. Students should be responsible for and actively involved in their own learning.

Although he tried hard to relate the subject matter to day-to-day life and asked many questions to guide the students, he was not very successful in promoting student-to-student interaction. When the students could not answer a question, he attempted to involve them in the subject matter by asking new discussion questions or doing an activity. However, it was the first time the students were introduced to the concepts of modern Physics; therefore, they might not be able to engage fully in learning activities due to the abstract nature of the subject matter.

His self-evaluation was consistent with his practice because he gave similar responses, and added: "I intended to expose the students to group work and interaction while doing the activities. My only goal was to get them to give answers and question what they are learning, however, I could not engage them enough." We cannot, however, state that his views were consistent with his actions regarding the learning process.

Views on Learning Environment: He emphasized the importance of stimulating students' curiosity, raising questions in their minds and encouraging them to give their own answers and of teacher's role as a guide as they do that. He stated that it was necessary to ask students questions, the answers to which are not directly numerical but those of which should be interpreted. He noted that the teachers that he observed during his internship provided a suitable environment for interpretation, questioning and active participation. He explained the method which he thinks teachers should use as follows:

Direct instruction is not appropriate because students get bored and pay no attention. It is important to raise questions in students' minds and to make sure they get the result like in the 5E or 7E model. It may not work out for every course, but I think that physics can be taught like that.

During his presentation, he gave the students enough time to express themselves and encouraged them to tell their views (e.g., "I think that your answer is ready in your head, so you can just say the words. Please share your views"). He also asked why and what questions about the subject matter such as "Why has it not changed?" "What kind of comments can we make on it?" and "What did you understand?" After all, although the classroom environment that he created during his performance was directly related to his views, he was not successful in mobilizing the students and involving them as he had planned, probably due to the same reason, that is, the abstract nature of the subject matter. 
Views on Assessment: He addressed the importance of asking interpretational questions instead of formula-based ones. He highlighted the significance of providing students with the opportunity to discuss questions posed, giving enough time for activities and guiding them while assessing their performance.

However, the students did not interact much with each other and participate in the discussions during his teaching performance. Although he frequently asked questions to check whether they had understood the concepts, he could not assess them well, and summarized the topic at last. We can state that his views and actions about assessment were consistent since he was categorized as transitional according to both the observation and interview results.

Overall Perspective: Among all participants, Hakan had the highest observation and interview scores. Therefore, his views and actions were analyzed in terms of the constructivist profile. When asked if he could fulfill his professional requirements, he responded "I think that I can improve myself since I always think about how to teach physics." He gave the following response to the second interview question that queried about participants' perceived levels: "I am sure that I will be a constructivist teacher. My aim is to get to the seventh level, but I think that I am on the fifth or sixth level." His statements and observation results for all dimensions show that he interpreted and implemented the constructivist view of teaching best. He prepared a lesson plan to reveal students' prior knowledge and stimulate their curiosity, and asked them many open-ended questions to raise their awareness of misconceptions about the topic he covered. Although he stated that he would use cooperative learning as a teaching method, he used questioning and discovery methods during his teaching performance. He was not very successful in getting students to interact with each other and to actively engage in the learning process.

\section{Case 2: Deniz (Transitional Profile)}

Deniz was categorized as transitional for all the dimensions according to the interview and observations results. Therefore, she was selected as the case representing the transitional profile.

Views on Beginning of a Lesson: Deniz explained her views as follows:

As the lesson begins, teachers should say what they intend to teach and what the topics to be covered on that day are. They should use real-life examples that are relevant to the course content. In this way, not only does the topic become more concrete, but also students 'warm up' to it. If the students have already covered it before, then the teacher may remind them of the content of the previous lessons.

Although she seemed to have some constructivist principles, her main goal was not to assess the students' prior knowledge and to evaluate the process in which they have conceptualized the concepts in their minds, but to measure what they know or remember. For example, her presentation was about the subject of electricity and magnetism (current and potential difference). First, she showed the photo and diagram of a hair dryer and asked students to give examples of conductive and insulative materials. She handed out a worksheet in the form of fill-in-the-blanks but answered the questions without waiting for the students to answer. Although she had a basic understanding of constructivism, the explanations that she made during her teaching performance showed that she did not have a solid grasp of the concept. We can therefore state that her views were consistent with her actions since both were categorized as transitional.

Views on Learning Process: Deniz stated that students should be in an environment where they are encouraged to construct knowledge themselves and improve their thinking and interpreting skills but she added that it would take too much time. She said that she would rather give questions as a homework assignment and do in-class activities on her own. These statements again show that she has transitional views as she believes that constructivist principles can not be applied to physics education in general due to time constraints. She stated that the reason why she would rather continue with the lecture and cover the material was time constraints. Consistent with her views, she did not get the students to participate in class activities and interact with each other. She posed some questions that would stimulate discussion. However, the students did not have enough time to discuss them.

Views on Learning Environment: Deniz expressed what kind of learning environment she would like to create as follows:

I think that I would emphasize the important parts of the topic and use worksheets when necessary. I would like to use brainstorming technique. In this way, students' critical thinking and interpretation skills would develop. I could use worksheets to highlight the important points to save time. I might conduct experiments as long as I have the necessary materials in the classroom. I would like to use the problembased learning method so that students would be able to think critically and find solutions to problems.

It is obvious that there are some contradictions in her statements. She sometimes emphasizes the importance of students' constructing understanding of knowledge for themselves while some other times she states that she would conduct experiments to show students how to put theories into practice and to explain subjects by giving them necessary formulas. Similar contradictions were noted during the observations as well. She asked the students some questions to encourage them to share their views. However, when they gave one-word answers, she did not elaborate on her plan or request feedback from the other students. Although she had planned a discussion based on analogies prior to teaching practice, she drew the analogies herself without asking the students any questions or giving them the 
opportunity to draw their own analogies. What is more, she asked many questions and handed out worksheets, however, she did not give the students enough time to answer the questions or complete the worksheets. She answered the questions and made the relevant connections herself.

Views on Assessment: She explained her views about assessment as follows:

Assessment should be process-oriented. For example, at the beginning of the class, I let students give reallife examples of the topic and ask them knowledge level questions. At the end of the class, I ask them the evaluation questions in the book and questions about the important points that I have explained. If they cannot answer the questions, I go over the subject matter.

On the one hand, she stated that she would ask the students questions to lead them to draw connections between the beginning and the end of the class while, on the other hand, she talked about her plans to ask them knowledge level questions. Similarly, her lesson plan and the worksheets that she used during her presentation showed that her goal was not to make a process-oriented assessment. She just wanted to make sure that the students learned the subject matter well.

Overall Perspective: Deniz does not have a sound understanding of the constructivist view of teaching and learning. She is inconsistent in her views and actions. The activities in her lesson plan are designed to explain topics better and to use time efficiently, not designed to guide students' knowledge constructing process or to make process-oriented assessments or to improve their critical thinking skills. She stated that she made her lesson plan to teach and that she would use worksheets and activities to stimulate the students. However, the worksheets she prepared consisted of activities, experiments and their results. Her worksheets are, therefore, not compatible with the process-oriented assessment approach.

She defined a qualified physics teacher as a subject matter expert conducting experiments and activities. When asked about her mentor teacher, she stated "He implements direct instruction method and does not monitor students' understanding. Although he asks open-ended questions, he cannot activate the students." We can say that there are similarities between her comments about her mentor teacher and her presentation.

She gave the following response to the second interview question as follows:

I think I am on the fourth level. I cannot get far from the traditional way of instruction, but I am still trying to be a constructivist teacher. I am trying to let students construct their knowledge and to make them actively engaged in their learning, but I don't seem to achieve that. That is why I feel like I am on the level between a constructivist and a traditional teacher.

\section{Case 3: Murat (Traditional Profile)}

Murat was categorized as traditional according to both the observation notes and all interview dimensions. He was, therefore, selected as the case with the traditional profile or with a weak understanding of constructivist learning/teaching.

Views on Beginning of a Lesson: During the interview, Murat talked about the necessity of telling students the objectives of the course, explaining to them the lesson plan at the beginning of a lesson and then lecturing by providing them with the necessary definitions and information. He believes that knowledge is transferred from teacher to students, and therefore, he does not pay attention to students' prior knowledge, which is part of traditional understanding. In line with his views, he started his presentation stating the topic (current and potential difference) and giving some examples of it in daily life. Then, he showed how to make a simple electric circuit and explained the functions of the circuit elements. We can therefore argue that his statements during the interview and his actions were consistent as to how to start a lesson.

Views on Learning Process: Murat emphasized the need for a silent environment for the teacher to teach. When asked about his mentor teacher, he stated as follows:

My mentor teacher is the best one I have ever seen. The students would listen to him quietly. He mostly uses the blackboard, hands out some worksheets and solves problems. At the end of the lesson, he hands out the worksheets that he has prepared from the books as a homework assignment.

He described a system in which students listen to their teacher and study at home. His views are similar to the traditional viewpoint in which students are passive listeners and do not actively engage in their learning process. In his presentation, he handed out worksheets at the end of the lesson and gave it as a homework assignment, as does his mentor teacher. Thus, he does not believe in a learning process consisting of interaction, interpretation and feedback.

Views on learning environment: Murat stated that teachers should create an environment in which they present facts fluently in accordance with their lesson plans and students listen to their teachers and take notes. He believes that if teachers create that kind of environment, they are then considered qualified teachers. Murat's actions were consistent 
with his views since he presented facts while the students listened to him and took notes without asking any questions and without participating in the lesson.

Views on assessment: When asked about how assessment should be conducted, he said "If the teacher cannot do an activity, he/she can give a written exam. After explaining the necessary concepts and information to students, he/she can ask a few questions to measure their level and to get feedback. He gave an example question (Do you remember the units of the current and potential?) that can be asked to get feedback. It is doubtful whether a teacher can monitor and evaluate students' mental structures with that kind of knowledge level questions.

During his presentation, although he asked some questions, he could not get an answer. He handed out a worksheet consisting of fill in the blanks questions. Taking both the interview and observation results into consideration, we categorized him as the traditional profile because he does not consider assessment to be a process. He thinks that students should be assessed at the end of the process, especially via written exams.

Overall Perspective: We can state that he is the only prospective teacher whose views are consistent with his actions in all dimensions. During the interview, he favored traditional teacher characteristics and acted in that way while presenting the topic. It was obvious from his lesson plan that he aimed to implement direct instruction method. Therefore, his lesson plan and presentation were consistent in that context.

Murat criticized the teachers whom he observed during his internship as follows:

They are still teaching based on the old curriculum. I don't think that they have accepted the new curriculum and are ready to apply it yet. I did not see any teacher trying to do activities or experiments... I think that important things, like in the new curriculum, should be taught rather than details.

Based on his comments and his definition of the new curriculum as merely doing activities, we can state that he did not fully understand or internalize the philosophy of the curriculum. When asked to evaluate his level of understanding and his presentation, he placed himself on the fourth level, which actually does not correspond with his presentation and comments. This inconsistency may be due to his misinterpretation of the curriculum. It is, therefore, not surprising that he considers himself a moderate performer because he set up a circuit, showed it to the students and handed out a worksheet at the end of the lesson.

\section{Conclusions and Implications}

The aim of this study was to investigate prospective physics teachers' views of teaching and learning process, to examine their instructional practices and to explore the consistency between their views and instructional practices. Semi-structure interviews were conducted to gain insight into prospective physics teachers' views of constructivism. Observations were carried out and lesson plans were examined as well. As a result of all analysis, three cases were selected to represent traditional, transitional and constructivist teacher profiles, and their views and practices were compared. The results showed that most participants had either transitional or traditional profile. Similar results were reported by Demirci (2015), Lederman (1992), Tsai (2002), Unal and Akpinar (2006) and Uzuntiryaki et al. (2010).

All three cases exhibited some similarities to their mentor teachers regarding their understanding of teaching/learning process and implementation of the curriculum. The aim of practical courses offered to students is to inform them on different teaching methods, to enable them to develop a perspective on teaching and school environment and to provide them with the opportunity to apply their knowledge in a real classroom environment. Mentor teachers' view of teaching is, therefore, crucial. If they do not guide prospective teachers and support them to use constructivist teaching methods/strategies in line with the curriculum, it may affect prospective teachers' way of teaching and prevent them from using such methods/strategies in their future professional lives. Establishing mentor-protégé relationship between teachers and prospective teachers is a step in this direction. Haney and McArthur (2002) state that if prospective teachers develop a constructivist synergy with their mentor teachers, they will be more likely to put their views into practice.

During the interviews, all participants stated that mentor teachers did not use course books and that most students did not have the appropriate characteristics for the curriculum. Although participants have incomplete information on the philosophy of the constructivist program, it is clear from their interpretation that students are still taught in a teachercentered classroom environment in which they are passive recipients of knowledge. It would, therefore, be contradictory to expect prospective teachers to practice teaching based on the constructivist philosophy. Caleon et al. (2018) and Mansour (2013) argue that this inconsistency may be due to the fact that teachers modify their practices according to students' needs and a variety of instructional contexts such as exam-oriented systems and time constraints. These factors may force them to use more traditional or transitional-oriented activities in the Turkish education system, which is also exam-oriented. Therefore, these factors should be considered in order to develop strategies to prevent or manage those barriers.

Instructors, especially those teaching practical and/or other methodology courses in the faculties of education, may also have an effect on prospective teachers. Participants claimed that almost all instructors taught their courses in a traditional format. Only in the Methods of Teaching course, participants apply different teaching methods, yet without 
professional experience. It is, therefore, reasonable to find that none of the participants were categorized as constructivist as a result of the observations despite the fact that some of them had constructivist views. Brooks and Brooks (1993) emphasize the importance of constructivist-based teacher education programs that promote teaching practices that encourage students' participation in their own learning and construction of their own understanding. As they state "the philosophical underpinnings of the theories and practices to which pre-service teachers are exposed have a lasting impact on their perception of the teaching role" (p.121). Teachers more readily understand and practice constructivist methodologies if they are exposed to specific programs based on constructivist principles and if they are provided with opportunities to construct their own educational visions (Brooks \& Brooks, 1993).

It was observed that participants did not aim to use constructivist teaching methods in their lesson plans (problembased learning, cooperative learning, etc.), most of which included the question technique in particular. Although participants asked their students many questions, very few students were able to engage in the process, which may be because participants did not construct the questions correctly, did not take into account the students' readiness levels, did not give them enough time to answer the questions and were unable to paraphrase the questions. Students' critical thinking skills do not improve if questions are not properly constructed. If students do not understand the questions, there will be no discussion and interaction between them. It is necessary to have a good grasp of a subject-matter in order to be able to ask effective questions about it. Although participants planned some constructivist techniques, most of them were not able to use them in their presentations. Most participants included some demonstration experiments or drawings as multiple intelligence techniques in their lesson plans. Thus, the adequacy of the method courses offered by the faculties of education and how they are taught should also be questioned.

Holt-Reynolds (2000) states that prospective teachers' prior experiences during their education life play a significant role in the development of their teacher identity and teaching perspectives. Prospective teachers not only take methods of teaching courses, observe their mentor teachers and have two semesters of experience of teaching during their undergraduate education, but also spend almost 12 years developing their views of teaching and learning during their primary and secondary education. Students' prior experiences (passive learning style) also act as a barrier to prospective physics teachers' constructivist teaching (Tupsai, Yuenyong, \& Taylor, 2015). Therefore, primary and secondary school teachers' teaching/learning processes should be analyzed, in-service training should be made available and students should be provided with constructivist learning environments.

A limitation of this study was the time allowed for observations. Therefore, further studies with longer and much detailed observation periods are required to better understand and discuss the pedagogical orientations of prospective physics teachers.

\section{References}

Aguirre, J. M., Haggerty, S. M., \& Linder, C. J. (1990). Student-teachers' conceptions of science, teaching and learning: A case study in preservice science education. International Journal of Science Education, 12(4), 381-390. https://doi.org/10.1080/0950069900120405

Appleton, K., \& Asoko, H. (1996). A case study of a teacher's progress toward using a constructivist view of learning to inform teaching in elementary science. Science Education, 80(2), 165-180.

Ates, O., \& Eryilmaz, A. (2011). Effectiveness of hands-on and minds-on activities on students' achievement and attitudes towards physics. Asia-Pacific Forum on Science Learning and Teaching, 12(1), 1-22.

Bassey, M. (1999). Case study research in educational settings (doing qualitative research in educational settings) (1st ed.). Maidenhead, UK: Open University Press.

Boulton-Lewis, G. M., Smith, D. J. H., McCrindle, A. R., Burnett, P. C., \& Campbell, K. J. (2001). Secondary teachers' conceptions of teaching and learning. Learning and Instruction, 11(1), 35-51. https://doi.org/10.1016/S09594752(00)00014-1

Boz, Y., \& Uzuntiryaki, E. (2006). Turkish prospective chemistry teachers' beliefs about chemistry teaching. International Journal of Science Education, 28(14), 1647-1667. https://doi.org/10.1080/09500690500439132

Brickhouse, N. (1990). Teachers' beliefs about the nature of science and their relationship to classroom practice. Journal of Teacher Education, 41, 53-62. https://doi.org/10.1177/002248719004100307

Brooks, J. G., \& Brooks, M. G. (1993). In search of understanding: The case for constructivist classrooms. Alexandria, VA: Association of Supervision and Curriculum Development.

Bryan, L. A., \& Gustafson, Brenda; Rowell, P. M. (2003). Nestedness of beliefs: Examining a prospective elementary teacher's belief system about science teaching and learning. Journal of Research in Science Teaching, 40(9), 835868. https://doi.org/10.1080/0950069950170504

Caleon, I. S., Tan, Y. S. M., \& Cho, Y. H. (2018). Does teaching experience matter? The beliefs and practices of beginning and experienced physics teachers. Research in Science Education, 48(1), 117-149. 
https://doi.org/10.1007/s11165-016-9562-6

Cornett, J. W., Yeotis, C., \& Terwilliger, L. (1990). Teacher personal practical theories and their influence upon teacher curricular and instructional actions: A case study of a secondary science teacher. Science Education, 74(5), 517529. https://doi.org/10.1002/sce.3730740503

Cronin-Jones, L. L. (1991). Science teacher beliefs and their influence on curriculum implementation: Two case studies. Journal of Research in Science Teaching, 28(3), 235-250. https://doi.org/10.1002/tea.3660280305

Demirci, N. (2015). Prospective high school physics teachers' beliefs about teaching practices: From traditionalist to constructivist. Eurasia Journal of Mathematics, Science and Technology Education, 11(3), 693-711. https://doi.org/10.12973/eurasia.2015.1332a

Dillon, D. R., O’Brien, D. G., Moje, E. B., \& Stewart, R. A. (1994). Literacy learning in secondary school science classrooms: A cross-case analysis of three qualitative studies. Journal of Research in Science Teaching, 31(4), 345-362. https://doi.org/10.1002/tea.3660310405

Duru, S. (2006). Pre-service elementary education teachers' beliefs about teaching and learning in Turkey. Unpublished PhD Thesis in Indiana University School of Education, Bloomington, Indiana.

Gustafson, B. J., Rowell, P. M., \& Gustafson, Brenda J. ; Rowell, P. M. (1995). Elementary preservice teachers: Constructing conceptions about learning science, teaching science and the nature of science. International Journal of Science Education, 17(5), 589-605. https://doi.org/10.1080/0950069950170504

Hancock, E. S., \& Gallard, A. J. (2004). Preservice science teachers' beliefs about teaching and learning: The influence of k-12 field experiences. Journal of Science Teacher Education, 15(4), 281-291.

Haney, J. J., \& Mcarthur, J. (2002). Four case studies of prospective science teachers' beliefs concerning constructivist teaching practices. Science Education, 86(6), 783-802. https://doi.org/10.1002/sce.10038

Hashweh, M. (1996). Effects of science teachers' epistemological beliefs in teaching. Journal of Research in Science Teaching, 33, 47-63. https://doi.org/10.1002/(SICI)1098-2736(199601)33:1\%3C47::AID-TEA3\%3E3.0.CO;2-P

Hewson, P. W., \& Hewson, M. G. (1988). An appropriate conception of teaching science: A view from studies of science learning. Science Education, 72(5), 597-614. https://doi.org/10.1002/sce.3730720506

Holt-Reynolds, D. (2000). What does the teacher do? Constructivist pedagogies and prospective teachers' beliefs about the role of a teacher. Teaching and Teacher Education, 16(1), 21-32.

Jenkins, E. W. (2000). Constructivism in school science education: Powerful model or the most dangerous intellectual tendency? Science \& Education, 9, 599-610.

Justi, R. S., \& Gilbert, J. K. (2002). Science teachers' knowledge about and attitudes towards the use of models and modelling in learning science. International Journal of Science Education, 24(12), 1273-1292. https://doi.org/10.1080/09500690210163198

Lederman, N. G. (1992). Students' and teachers' conceptions of the nature of science: A review of the research. Journal of Research in Science Teaching, 29(4), 331-359. https://doi.org/10.1002/tea.3660290404

Mansour, N. (2013). Consistencies and inconsistencies between science teachers' beliefs and practices. International Journal of Science Education, 35(7), 1230-1275. https://doi.org/10.1080/09500693.2012.743196

Mellado, V. (1997). Preservice teachers' classroom practice and their conceptions of nature of science. Science and Education, 6(4), 331-354.

Mellado, V. (1998). The classroom practice of preservice teachers and their conceptions of teaching and learning science. Science Education, 82, 197-214.

Merriam, S. B. (1998). Qualitative research and case study applications in education (2nd ed.). San Francisco: Jossey-Bass Publishers.

Munby, H. (1982). The place of teachers' beliefs in research on teacher thinking and decision making, and an alternative methodology. Instructional Science, 11(1), 201-225. https://doi.org/10.1007/BF00414280

Munby, H., Cunningham, M., \& Lock, C. (2000). School science culture: A case study of barriers to developing professional knowledge. Science Education, 84, 193-211.

Nespor, J. (1987). The role of beliefs in the practice of teaching. Journal of Curriculum Studies, 19(4), 317-328. https://doi.org/10.1080/0022027870190403

Ogan-Bekiroglu, F., \& Akkoc, H. (2009). Preservice teachers' instructional beliefs and examination of consistency between beliefs and practices. International Journal of Science and Mathematics Education, 7(1), 1173-1199. 
https://doi.org/10.1007/s10763-009-9157-z

Pajares, M. F. (1992). Teachers' beliefs and educational research: cleaning up a messy construct. Review of Educational Research, 62(3), 307-332. https://doi.org/10.3102/00346543062003307

Porlán, R., Martín, R., \& Pozo, D. (2004). The conceptions of in-service and prospective primary school teachers about the teaching and learning of science. Journal of Science Teacher Education, 15(1), 39-62. https://doi.org/10.1023/B:JSTE.0000031462.40615.56

Prawat, R. S. (1992). Teachers' beliefs about teaching and learning: A constructivist perspective. American Journal of Education, 100(3), 354-395. https://doi.org/10.1086/444021

Qhobela, M., \& Kolitsoe Moru, E. (2014). Examining secondary school physics teachers' beliefs about teaching and classroom practices in lesotho as a foundation for professional development. International Journal of Science and Mathematics Education, 12(6), 1367-1392. https://doi.org/10.1007/s10763-013-9445-5

Savasci, F., \& Berlin, D. F. (2012). Science teacher beliefs and classroom practice related to constructivism in different school settings. Journal of Science Teacher Education, 23(1), 65-86. https://doi.org/10.1007/s10972-011-9262-z

Seda Cetin, P., Kaya, E., \& Geban, O. (2014). Students', pre-service teachers' and in-service teachers' views about constructivist implementations. Necatibey Faculty of Education Electronic Journal of Science and Mathematics Education, 8(2), 143-163. https://doi.org/10.12973/nefmed.2014.8.2.a7

Simmons, P. E., Emory, A., Carter, T., Coker, T., Finnegan, B., Crockett, D., ... Spector, B. (1999). Beginning teachers: Beliefs and classroom actions. Journal of Research in Science Teaching, 36(8), 930-954.

Smith, D. C., \& Neale, D. C. (1989). The construction of subject matter knowledge in primary science teaching. Teaching and Teacher Education, 5(1), 1-20. https://doi.org/10.1016/0742-051X(89)90015-2

Tobin, K., \& Mcrobbie, C. J. (1996). Cultural myths as constraints to the enacted science curriculum. Science Education, $80(2), 223-241$.

Tsai, C.-C. (2002). Nested epistemologies: science teachers' beliefs of teaching, learning and science. International Journal of Science Education, 24(8), 771-783. https://doi.org/10.1080/09500690110049132

Tupsai, J., Yuenyong, C., \& Taylor, P. C. (2015). Initial implementation of constructivist physics teaching in Thailand: A case of Bass pre-service teacher. Mediterranean Journal of Social Sciences, 6(2), 506-513. https://doi.org/10.5901/mjss.2015.v6n2p506

Unal, G., \& Akpinar, E. (2006). To what extent science teachers are constructivist in their classrooms? Journal of Baltic Science Education, 2(10), 40-50.

Uzuntiryaki, E., Boz, Y., Kirbulut, D., \& Bektas, O. (2010). Do pre-service chemistry teachers reflect their beliefs about constructivism in their teaching practices? Research in Science Education, 40(1), 403-424. https://doi.org/10.1007/s11165-009-9127-z

Yin, R. K. (2009). Case study research: design and methods. (3rd ed.). Thousand Oaks, CA: SAGE Publications Inc. 


\section{Appendix}

Interview Guides

\section{First Interview Guide}

Could you explain in detail how you plan your physics lessons?

a- How do you start the lesson?

b- Do you pay attention to your students' prior knowledge? (If yes) How do you reveal it?

c- How do you continue your lesson after making an introduction? (learning environment, methods and strategies etc.)

d- What do your students do in the class? How do they learn? How much and how do you contribute to their learning?

e- How do you explain the subject matter?

f- What kind of activities do you prepare?

g- What kind of questions do you ask? Why?

h- How do you evaluate whether students have understood the lesson or not?

Second Interview Guide

1. Please choose the number that best reflects your teaching practice and philosophy on a scale of 1 to 7 , where 1 means "Traditional" and 7 means "Constructivist." Please explain briefly.

\begin{tabular}{|c|c|c|c|c|c|c|}
\hline 1 & 2 & 3 & 4 & 5 & 6 & 7 \\
\hline Traditional & 2 & 3 & \multicolumn{2}{c|}{ Constructivist } \\
\hline
\end{tabular}

2. Could you please evaluate your latest teaching practice? -regarding introduction, explanations, questions, learning environment, activities and evaluation. 